\title{
33. CRUSTACEAN COPROLITHS FROM TOPMOST JURASSIC OR BASAL CRETACEOUS DEPOSITS OF THE NORTHWESTERN PACIFIC
}

\author{
Roger Lehmann, Esso Production Research-European Laboratories, \\ 213, Cours Victor Hugo, 33321 Bègles France
}

\begin{abstract}
A calcite vein in the basalt from the bottom of Site 304 (Deep Sea Drilling Project, Leg 32) in the northwestern Pacific contains numerous and well-preserved crustacean coproliths which are attributed to the form-genus Favreina. They are closely related to Favreina salevensis (Paréjas), a "species" known to be widespread in deposits of Late Jurassic age. At Site 304, the sediments overlying the basalt are dated as Hauterivian or Valanginian based on calcareous nannoplankton.
\end{abstract}

\section{INTRODUCTION}

An approximately 2 -cm-wide calcite vein in the basalt of Core 16 of Site 304 (northwestern Pacific, Figure 1) contains numerous and well-preserved crustacean coproliths. Several veins of calcite, chalcedony, and celadonite exist in the dense, fine-grained, weathered, and relatively fracture-free basalt of Cores 15,16 , and 17 of Site 304, but crustacean coproliths were observed in only one vein (Sample 16-2, 45-60 cm). This particular vein is located in the middle part of a basalt unit which may be interpreted as a ponded flow with a thickness of at least 8 meters (comments on basalt by M.C. Marshall, U.S. Geological Survey, Menlo Park).

\section{REMARKS ON GENERIC AND SPECIFIC ATTRIBUTION}

The classification of the form-genera of crustacean coproliths by Brönnimann $(1955,1972)$ is mainly based on the shape of the interior canals as seen in sections perpendicular to the longitudinal axis of the coproliths.

The crustacean coproliths from the bottom of Site 304 show circular canals which characterize the form-genus Favreina. The other form-genera (Palaxius, Helicerina, Parafavreina, and Thoronetia) created by Brönnimann and coauthors (Brönnimann and Norton, 1961; Brönnimann and Masse, 1968; Brönnimann et al., 1972) can be excluded based on the different shape of their interior canals (Figure 2). The only other form-genus with rounded canals is Thoronetia, but it possesses a ventral cap which clearly differentiates it from Favreina.

The favreinids at Site 304 have been compared with all described species of Favreina. They are closely related to Favreina salevensis (Brönnimann and Zaninetti, 1972; Favre and Richard, 1927) and are therefore determined as Favreina sp. aff. F. salevensis (Figure 3). The differences with typical representatives of Favreina salevensis are discussed below.

\section{Favreina sp. aff. Favreina salevensis (Paréjas, 1948)} Plate 1, Figures 1-13

Locality: Site 304, Core 16, Section 2, 45-60 cm; northwestern Pacific, $39^{\circ} 20.77^{\prime} \mathrm{N}, 155^{\circ} 04.19^{\prime} \mathrm{E}$; depth below sea floor: 337.5-343.0 meters.

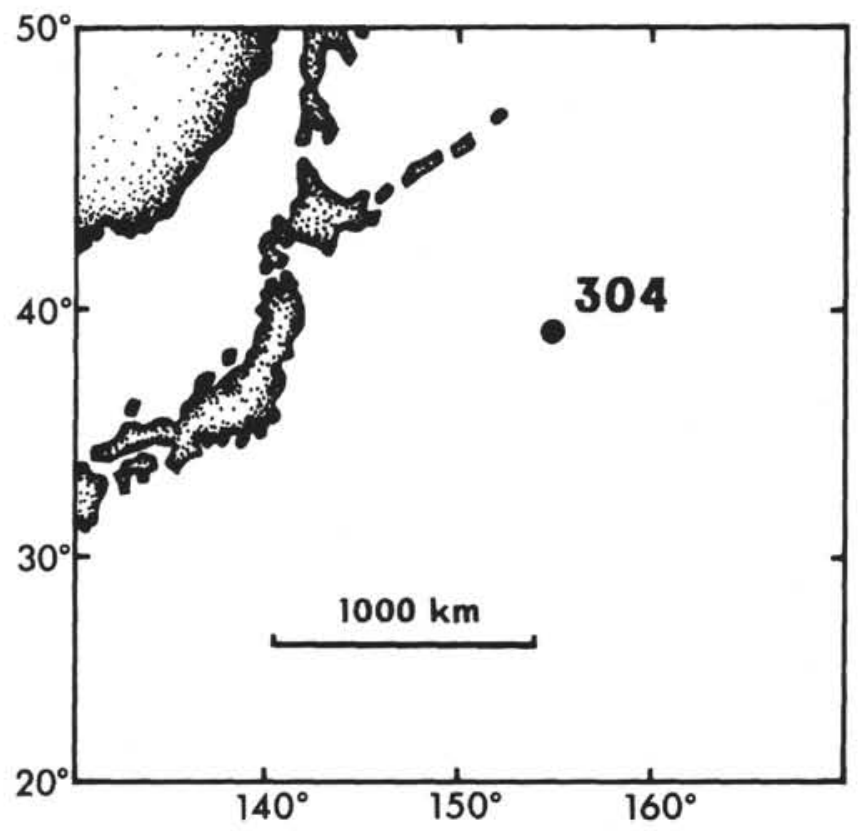

Figure 1. Location of Site 304, Leg 32 approximately 1000 $\mathrm{km}$ east of Japan.

\section{DESCRIPTION}

Cylindrical rods with rounded to subrounded vertical sections. Rounded longitudinal canals arranged in two horseshoe-like patterns which are symmetrical to a median line. The median rows of canals are straighter than the exterior ones which follow more or less the outline of the coproliths. The two median rows of canals may be linked by two canals at the rounded end of the horseshoes. In these specimens, the arrangement of the exterior canals is almost circular.

Commonly, 20 to 30 canals are cut in one vertical section. A single horseshoe consists of 10 to 14 canals, with 5 to 7 of them forming a beam.

The outline of the coproliths in longitudinal section is subrectangular. In many specimens four subparallel, continuous iines which correspond to the canals are visible. 

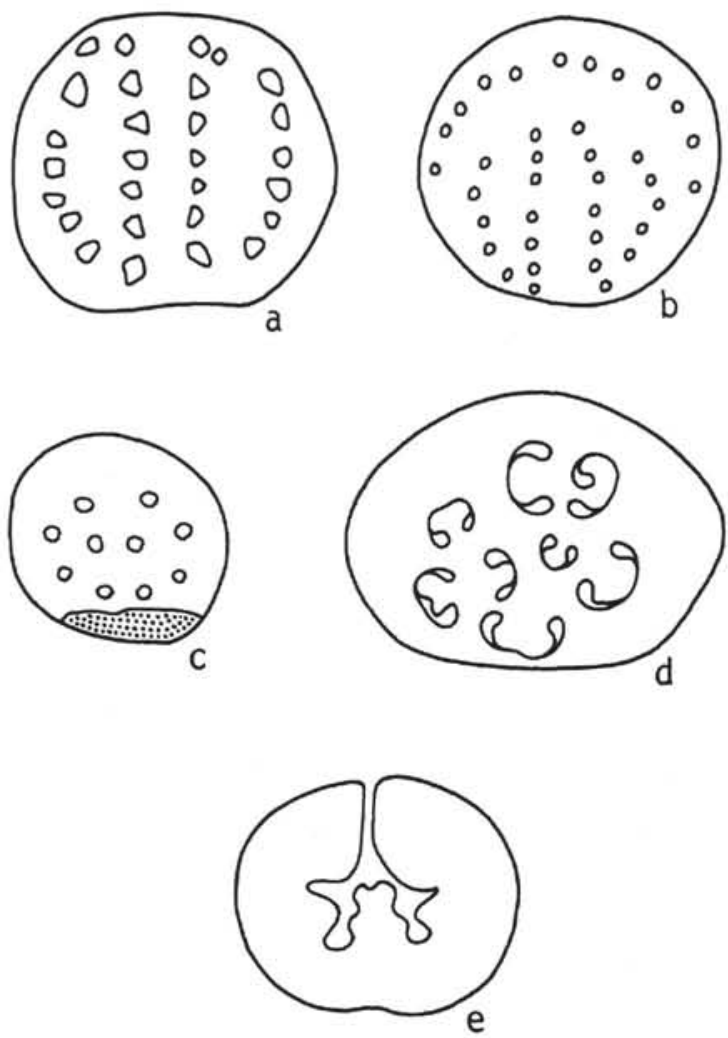

Figure 2. Vertical sections of form-genera introduced by P. Bronnimann (a) Parafavreina thoronetensis Bronnimann, Caron, and Zaninetti, X100; (b) Favreina salevensis (Parejas), X100; (c) Thoronetia quinaria Bronnimann, Caron, and Zaninetti, $\times 100 ;$ (d) Palaxius petenensis Bronnimann and Norton, $\times 50$; (e) Helicerina spinosa Bronnimann and Masse, $\times 200$.

Length of coproliths: $>1 \mathrm{~mm}$; diameter: 0.3 to 0.6 $\mathrm{mm}$.

\section{DISCUSSION}

In typical specimens of Favreina salevensis (Plate 2, Figures 1-8), an additional semicircular row of canals exists slightly above the open end of the horseshoes. These additional canals are not present in the specimens from the northwestern Pacific.

The continuity of the canals observed in longitudinal sections of Favreina sp. aff. F. salevensis (Plate 1, Figures $11,12)$ cannot be seen in typical Favreina salevensis (Plate 2, Figures 9, 10) in which the canals appear and disappear without having the subparallel character recognized in the specimens from Site 304.

Longitudinal sections of representatives of the genus Favreina from the Portlandian of southwestern France (Plate 2, Figures 14-17) are very similar to those of Favreina sp. aff. F. salevensis from Site 304. Up to seven subparallel canals can be seen in them. In vertical sections, however, the canals are scattered over the entire rounded to subrounded cut of the coprolith and display no bisymmetrical arrangement (Plate 2, Figures 11-13).

\section{AGE SIGNIFICANCE}

Favreina salevensis has been originally described from the Portlandian of the region of Geneva (Joukowsky and Favre, 1913). The species is known to be widespread
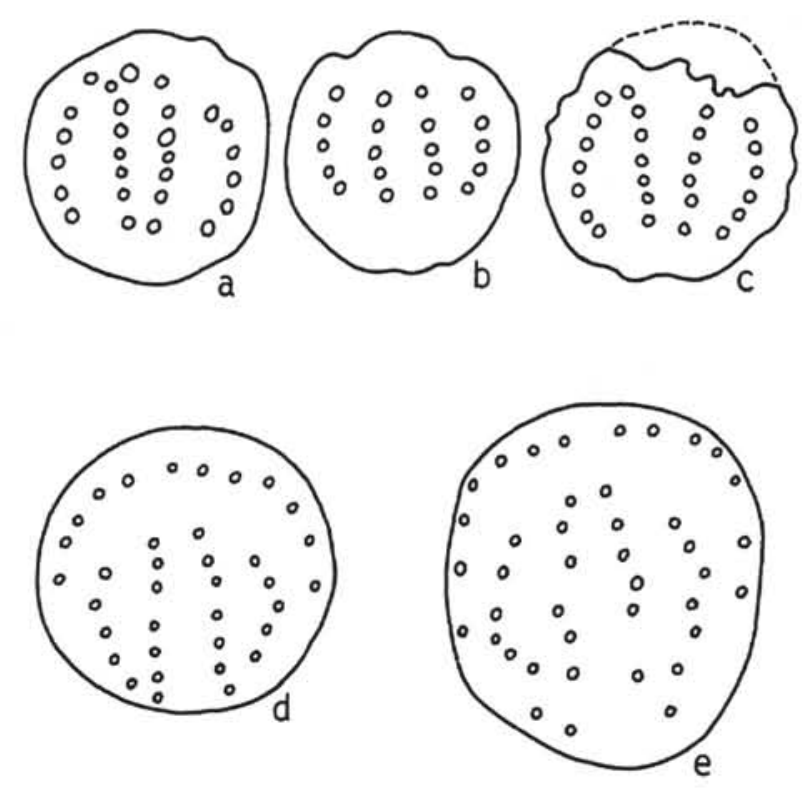

Figure 3. Vertical sections of $(a, b, c)$ Favreina $s p$. aff. F. salevensis (Parejas), $\times 50 ;(d, e)$ Favreina salevensis (Parejas), X100; (Parejas, 1935, fig. 1, 2)

in limestones of Late Jurassic age (e.g., Jura mountains, Provence-southern France, Texas, Cuba, Trinidad, Middle East). To my knowledge, Favreina salevensis has not been found in deposits of Early Cretaceous age. As the favreinids from Site 304 are close to, but not conspecific with Favreina salevensis, it would be tempting to infer a Late Jurassic age for the calcite vein containing them.

At Site 304, the oldest sediments immediately overlying the basalt are dated by calcareous nannoplankton as Hauterivian to Valanginian. The foraminiferal fauna from the same samples is tentatively attributed to the Barremian or Hauterivian.

As favreinids identical to Favreina sp. aff. F. salevensis from Site 304 are not yet known from well-dated samples, they are of only limited stratigraphic value. The specimens from Site 304 are tentatively placed into the topmost Jurassic-based on their affinity to Favreina salevensis-or into the basal Cretaceous-based on the age attributed to the overlying sediments.

\section{REFERENCES}

Brönnimann, P., 1955. Microfossils incertae sedis from the Upper Jurassic and Lower Cretaceous of Cuba: Micropaleontology, v. 1, p. 28-51.

1972. Remarks on the classification of Fossil Anomuran coprolites: Paläont. Z., v. 46, p. 99-103.

Brönnimann, P., Caron, J.P., and Zaninetti, L., 1972. New galatheid anomuran (Crustacea, Decapoda) coprolites from the Rhetian of Provence, southern France: Mitt. Ges. Geol. Bergbaustud., Innsbruck, v. 21, p. 905-920.

Brönnimann, P. and Masse, J.P., 1968. Thalassinid (Anomura) Coprolites from Barremian-Aptian passage beds, Basse Provence, France: Rev. Micropaléontol., v. 11, p. 153-160.

Brönnimann, P. and Norton, P., 1961. On the classification on fossil fecal pellets and description of new forms from Cuba, Guatemala and Libya: Ecolog. Geol. Helv., v. 53, p. 832842. 
Brönnimann, P. and Zaninetti, L., 1972. New names for favreine and parafavreine thalassinid anomuran (Crustacea, Decapoda) coprolites from the Jurassic of Greece and Algeria: Palăontol. Z., v. 46, p. 221-224.

Favre, J. and Richard, A., 1927. Etude du Jurassique supérieur de Pierre-Chatel et de la cluse de la Balme (Jura méridional): Mém. Soc. Paléontol. Suisse, v. 46, p. 1-39.
Joukowsky, E. and Favre, J., 1913. Monographie géologique et paléontologique du Salève (Haute-Savoie): Mém. Soc. Phys. Hist. Nat. Genève, v. 37, p. 295-524.

Paréjas, E., 1935. L'organisme B de E. Joukowsky et J. Favre: C.R. Séances Soc. Phys. Hist. Nat. Genève, v. 52, p. 221224.

1948. Sur quelques coprolithes de Crustacés: Archives Sci. Soc. Phys. Hist. Nat. Genève, v. 1, p. 512-520. 


\section{PLATE 1}

Favreina sp. aff. Favreina salevensis Sample 304-16-2, 45-60 cm.

Figures 1-8 Vertical sections, $\times 50$.

Figures 9, 10 Vertical sections, slightly oblique to longitudinal axis of coproliths, $\times 50$.

Figures 11, 13 Longitudinal sections, $\times 25$.

Figure 12 Calcite vein with coproliths. 
PLATE 1
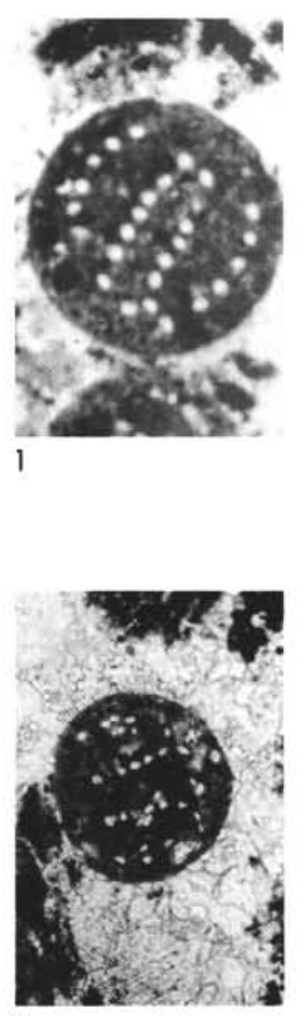

5
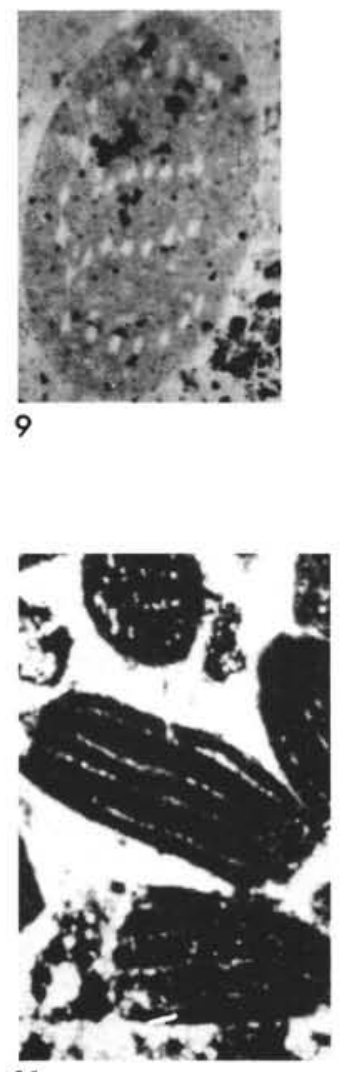
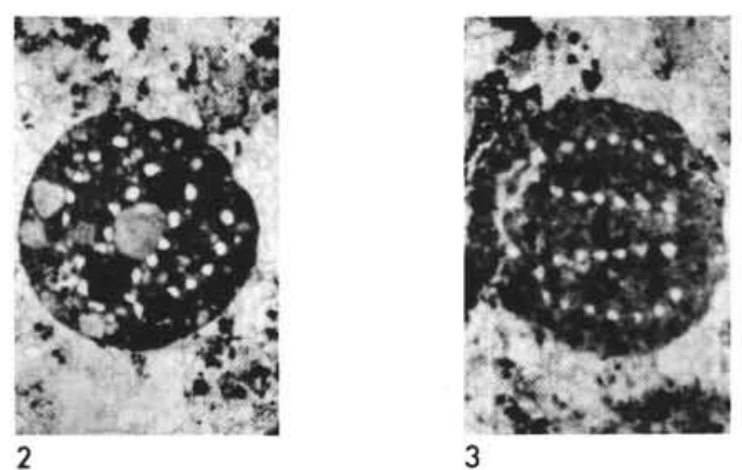

3
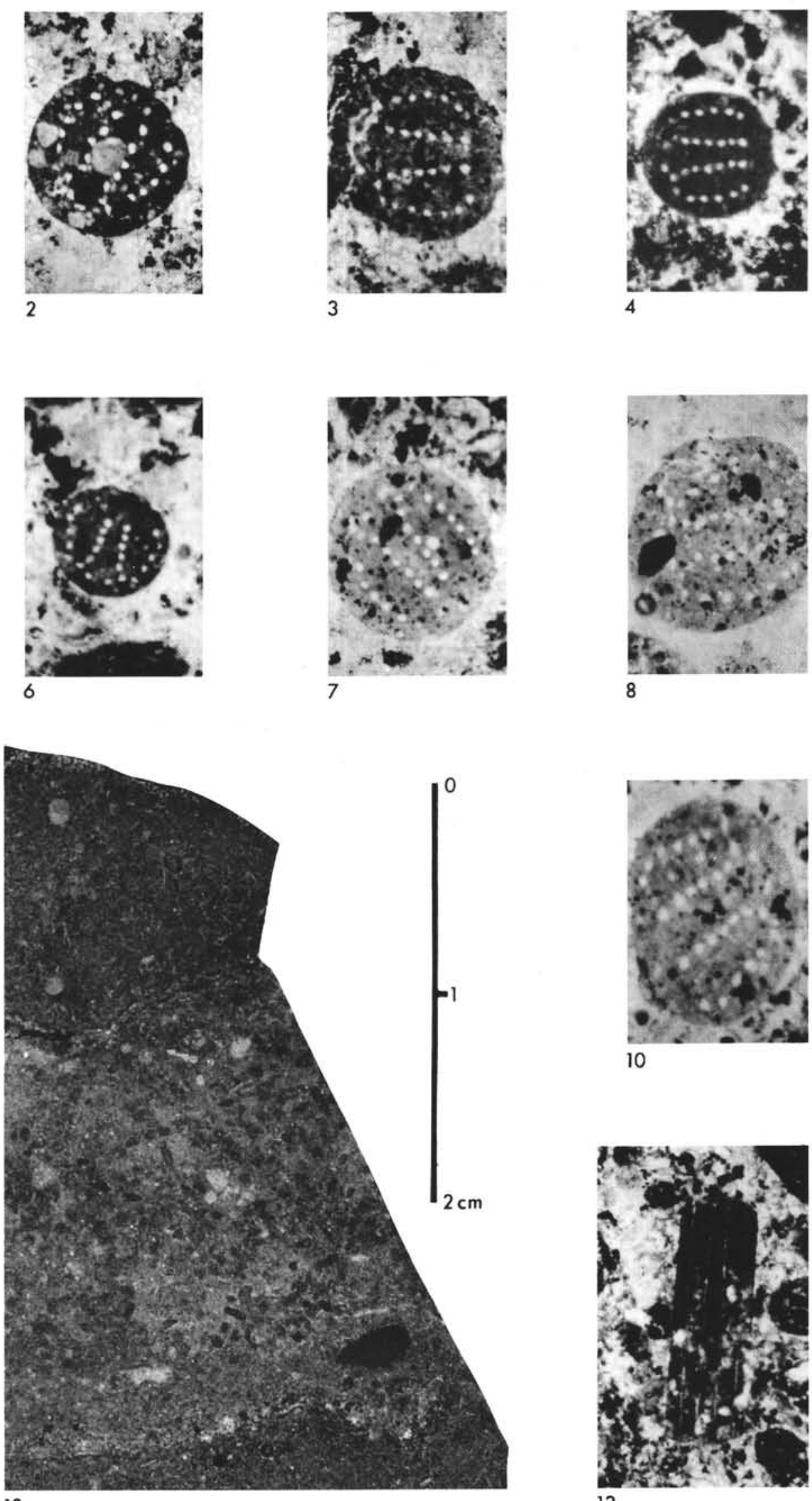
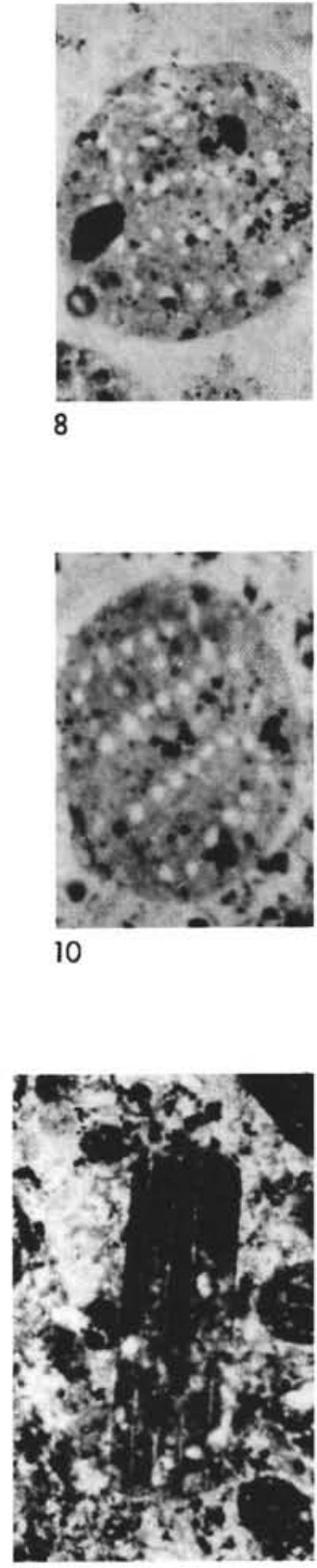

13 


\section{PLATE 2}

Figures 1-8 Favreina salevensis (Paréjas), Yenne section no. 23, DE 53 (Savoie, SE France), Portlandian-"Purbeckian." vertical sections, $\times 50$.

Figures 9, 10 Favreina salevensis (Paréjas), Yenne section no. 23, DE 53 (Savoie, SE France), Portlandian-"Purbeckian," longitudinal sections, $\times 25$.

Figures 11-13 Favreina sp., vicinity of Gourdon, BE 77 (Lot, SW France), Portlandian, vertical sections,. $\times 50$.

Figures 14-17 Favreina sp., vicinity of Gourdon, BE 77 (Lot, SW France), Portlandian, longitudinal sections, $\times 25$.

The material for this plate was kindly made available from the ESSO REP Exploration Department. 
PLATE 2
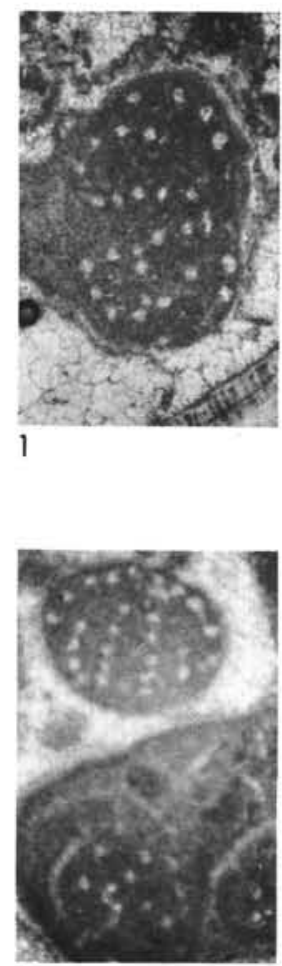

5
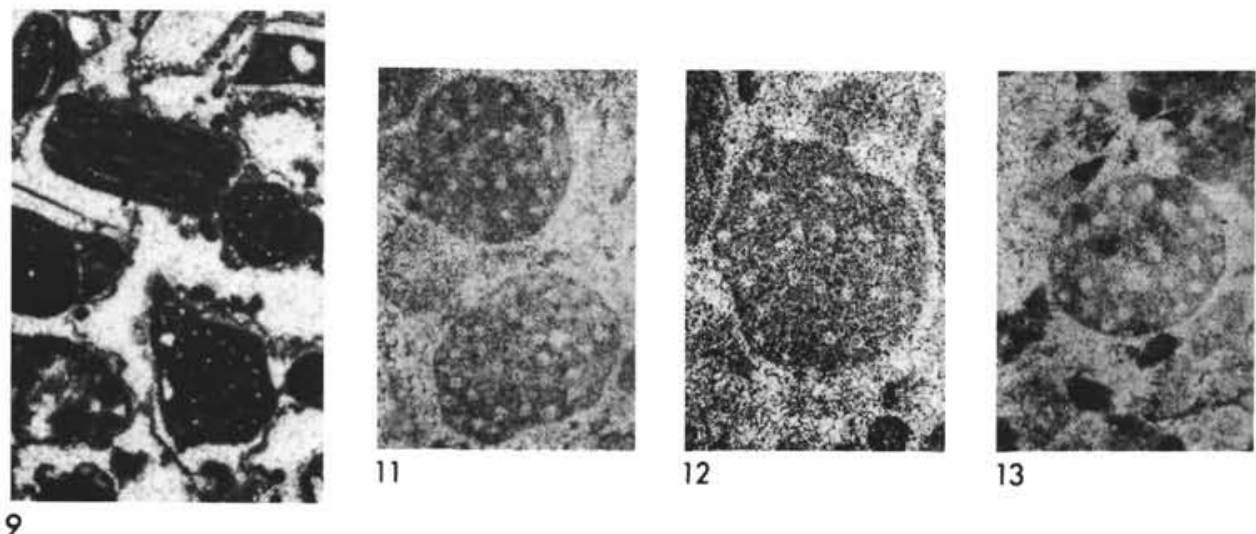

11
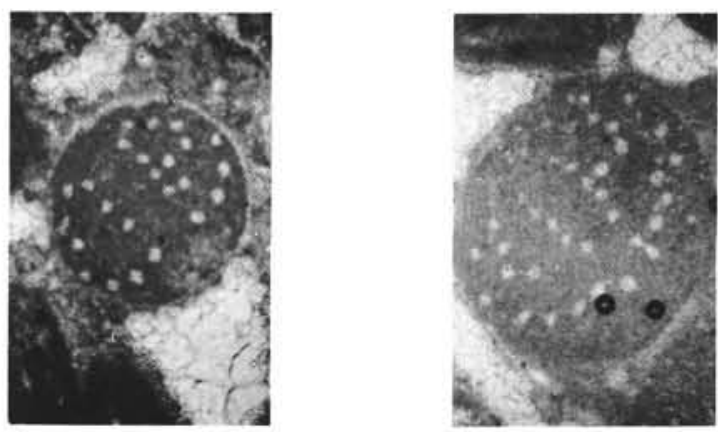

7

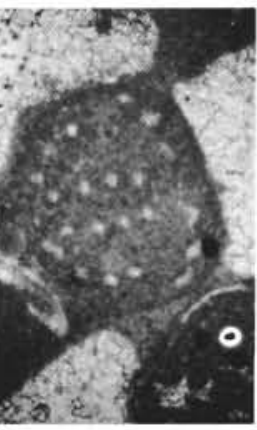

3
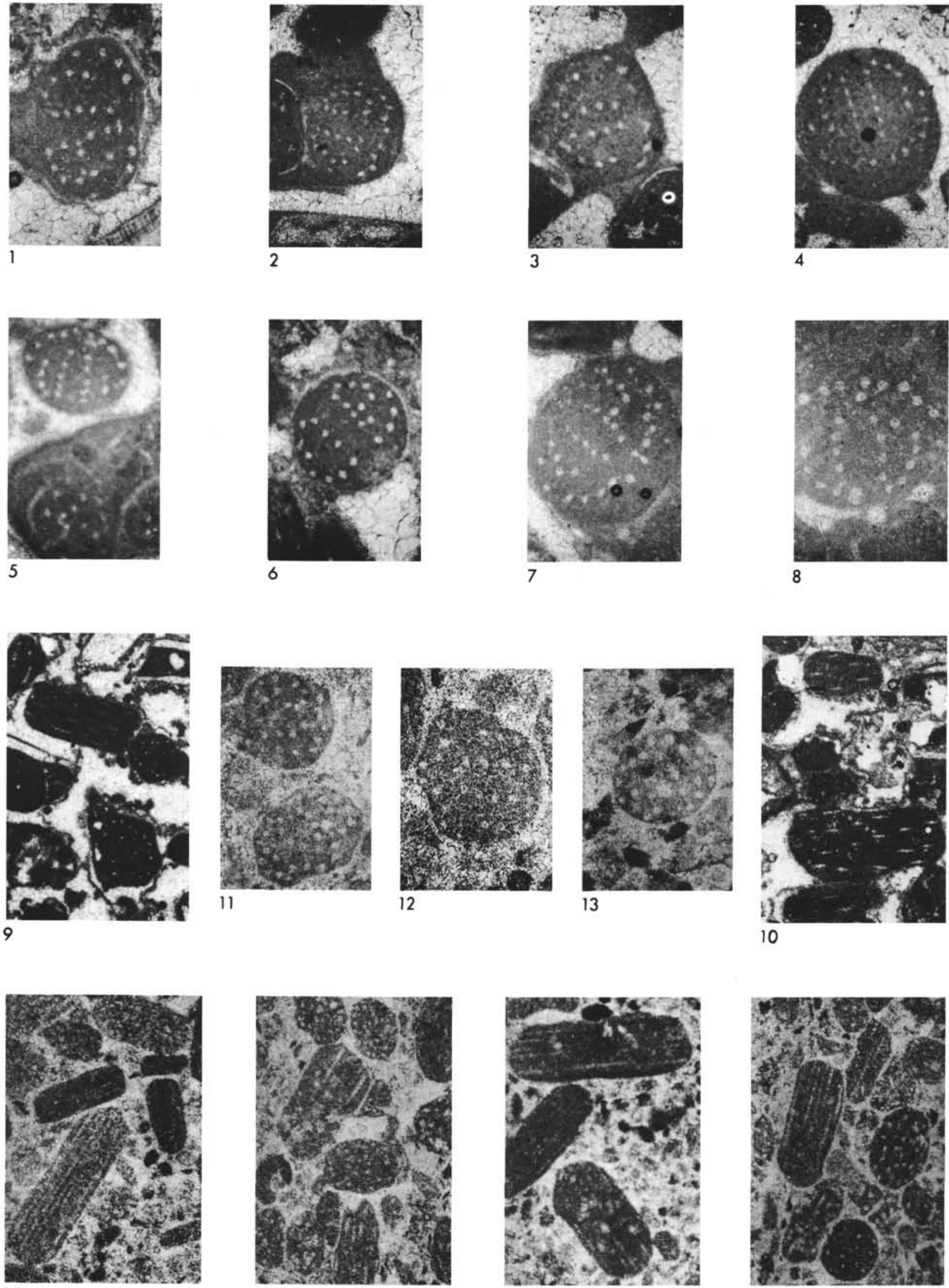

15

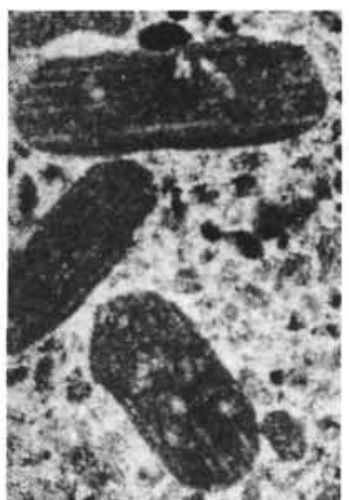

16

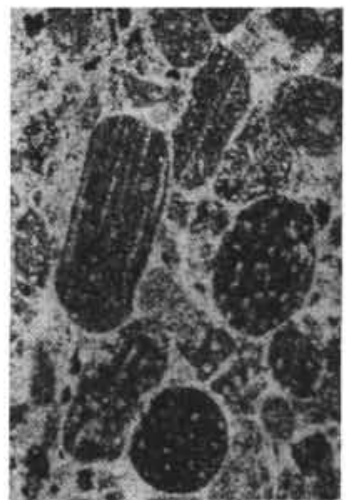

17 